\title{
Socioeconomic factors associated with tobacco smoking in Turkey: a cross-sectional, population-based study
}

Ceyda Sahan, ${ }^{1}$ Turkan Gunay, ${ }^{2}$ Hatice Simsek, ${ }^{2}$ Ahmet Soysal ${ }^{2}$ and Gul Ergor ${ }^{2}$

${ }^{1}$ Department of Occupational Medicine, Faculty of Medicine, Dokuz Eylul University, Izmir, Turkey. ${ }^{2}$ Department of Public Health, Faculty of Medicine, Dokuz Eylul University, Izmir, Turkey. (Correspondence to: Ceyda Sahan: ceyda.sahan@deu.edu.tr).

\begin{abstract}
Background: Gender and lower socioeconomic status are associated with smoking.

Aims: This study aimed to determine the association between socioeconomic factors and cigarette tobacco smoking in Balcova, Izmir, Turkey, with a focus on gender differences.

Methods: The study population was all men and women (36 187) aged over 30 years living in Balcova from October 2007 to May 2009. Data were collected in interviews and included smoking status (current, former, never), age, gender, marital status, educational level, occupational class/working status, health insurance and having a chronic disease. Logistic regression analysis was used to evaluate the association between socioeconomic characteristics and smoking status.

Results: Of the 36187 study subjects, 16080 (44\%) agreed to participate and $15174(42 \%)$ with complete data were evaluated. The majority were women (66.2\%); mean ages of men and women were 53.1 (SD 13.1) and 51.3 (SD 13.2) respectively. Current smoking was higher in men (41.7\% versus $31.2 \%$ of women), and more men were ex-smokers (33.1\% versus $13.5 \%$ of women) but more women had never smoked ( $55.3 \%$ versus $25.2 \%$ of men). For women, being married and having low educational level were associated with current smoking and previous smoking $(P<0.05)$. Current smoking was also more frequent among working women $(P<0.05)$. For men, low educational level and occupational class were associated with being a current smoker and an ex-smoker $(P<0.05)$.

Conclusions: Socially disadvantaged groups, especially those with low education or unemployed men, were more likely to be current smokers and smoking cessation was lower in these groups. Smoking habits were different in men and women. Socioeconomic factors should always be considered when developing smoking cessation policies.
\end{abstract}

Keywords: Tobacco smoking, gender, socioeconomic status, social class, Turkey

Citation: Sahan C; Gunay T; Simsek H; Soysal A; Ergor G. Socioeconomic factors associated with tobacco smoking in Turkey: a cross-sectional, population-based study. East Mediterr Health J. 2018;24(8):705-713. https://doi.org/10.26719/2018.24.8.705

Received: 01/05/15; accepted: 03/07/17

Copyright (c) World Health Organization (WHO) 2018. Some rights reserved. This work is available under the CC BY-NC-SA 3.o IGO license (https:// creativecommons.org/licenses/by-nc-sa/3.o/igo).

\section{Introduction}

People of low socioeconomic status are more likely to be less healthy than those of higher socioeconomic status, thus increasing their risk of noncommunicable diseases (NCDs) (1). Smoking is the primary cause of preventable NCDs and death, especially in developed countries (2). Smoking is the biggest health risk for heart diseases, various cancers, lung diseases and fertility problems, and it accelerates many other chronic illnesses (2). According to the World Health Organization (WHO), smoking prevalence in different regions of the world varies between $10 \%$ and $32 \%$ (3). In Europe, $41 \%$ of men and $22 \%$ of women smoke cigarettes, the highest rate of smoking for women in the world (3). In 1997, surveys demonstrated that more than $42 \%$ of men over the age of 25 years and just under $10 \%$ of women over 25 years were smokers in Turkey (4). Another study showed that smoking prevalence decreased by 42\% between 1995 and 2008 in Turkey (5). According to the Turkish Global Adult Tobacco Survey conducted in 2008 and 2012, smoking prevalence had decreased by $13 \%$ in adults (6).

In order to prevent smoking, various measures have been taken, such as raising the price of tobacco products, media campaigns intended for public education, and reducing the ways to get tobacco. However, the effectiveness of such measures depends on a variety of factors such as the financial, educational, social and demographic circumstances of the society (2).

According to WHO, "The social determinants of health are the conditions in which people are born, grow, work, live, and age, and the wider set of forces and systems shaping the conditions of daily life. These forces and systems include economic policies and systems, development agendas, social norms, social policies and political systems." (7). Socioeconomic determinants of health include age, gender and socioeconomic status. The most common indicators of socioeconomic status in modern industrialized populations are income, education and occupation (8). Income is often used as an indicator of socioeconomic status, but income is closely related to education and occupation. In many studies they are highly correlated and they can all be used to understand how socioeconomic status affects health behaviour (8). In addition, social class is defined as the degree of control 
over investments, decision-making, other people's work, and one's own work and is used to classify the socioeconomic status of people (8).

Reducing smoking prevalence to less than $12 \%$ was a goal of Healthy People 2020, but it has been achieved only for some population groups with higher education and income in the United States of America (USA) (9). Furthermore, success in decreasing smoking prevalence has been considerably slower in populations of low social status, as designated by low income, low levels of education, unemployment and blue-collar work (9). Smoking prevalence varies according to income level, educational status or occupational class (9-11), and lower socioeconomic status is a risk factor for increased smoking, especially in developed countries, and people of lower socioeconomic status are less concerned with smoking cessation $(10,11)$. The smoking rate among individuals of a society has 4 phases. In the first phase, smoking is rare in a society and restricted to the higher socioeconomic groups. In the second phase, smoking spreads among men and into other social classes. Although women take up smoking 10-20 years later than men, smoking also spreads among women, again beginning with the higher socioeconomic groups. In the third phase, smoking among the higher socioeconomic groups abruptly declines in men, but reaches a peak in women. In the fourth phase, smoking declines in general, but is widespread among the lower socioeconomic groups $(12,13)$.

Although in recent years smoking rates have been declining in Turkey (6), it may be important to protect disadvantaged groups more than before. It is crucial to evaluate all the factors influencing smoking habits in order to determine preventive public health policies. Thus, the prevalence of tobacco use needs to be evaluated according to various socioeconomic factors in different districts of Turkey.

The socioeconomic factors of smoking behaviour have been assessed in studies in Balcova, Turkey which were based on individuals in smoking cessation clinics $(14,15)$. The aim of this community-based study was to determine the association between cigarette smoking and socioeconomic factors in Balcova, with specific focus on gender differences.

\section{Methods}

\section{Study design, location and population}

This cross-sectional, community-based study was a part of the BAK project which aims to reduce cardiovascular disease (CVD) incidence and prevalence through reducing the risk factors $(16,17)$. The study population was 36187 people over 30 years of age living in Balcova District of İzmir, Turkey in 2007. The baseline study started in October 2007 and was completed in May 2009. All the study population (36187 people) were invited to participate in the survey, and 16080 (44\%) consented to participate. In this analysis, people whose data were incomplete were excluded so $15174(42 \%)$ people were finally evaluated.

\section{Data collection}

Data were collected through questionnaires completed by the interviewers $(16,17)$, and participants were interviewed at home. The interviewers were given information on the aims and background of the project and training on the questionnaires, communication skills, and risk factors of CVD diseases. A guideline was used during the interviews.

Data were collected on smoking status, defined as:

- current smoker: those who reported cigarette smoking every day or some days in the past month;

- ex-smoker: those who reported cigarette smoking in their lifetime, but who had not smoked for at least 1 month;

- never smoker: those who reported never smoking in their lifetime.

Participants were asked about the type of smoking (cigarettes, cigars, pipes and waterpipes). In this study only cigarette smoking was evaluated because smoking cigars, pipes or waterpipes was always additional to smoking cigarette.

Data were also recorded on age, gender, marital status, educational level, occupational class, working status, health insurance and having a chronic disease. We stratified the sample by gender because smoking and working status were very different in men and women as reported in other studies in Turkey $(6,18)$. Marital status was categorized as: married and other. Educational level was categorized as: completed primary school (or less); secondary school; high school; and university or higher. Low educational level was defined as completing primary school or less. Occupational class was categorized as: being an employer; self-employed; white collar worker; blue collar worker; and unemployed or having no regular income (19). Low occupational class was defined as being unemployed or having no regular income. We categorized the working status for women as: worker (having income-generating work) and non-worker. Having a chronic disease was defined as having a disease such as hypertension, diabetes mellitus, coronary heart disease, cerebrovascular disease, hypercholesterolaemia or cancer for at least 6 months.

\section{Data analysis}

Results are expressed as means and standard deviations (SD) or as percentages, and odds ratios and confidence intervals in the logistic regression analysis.

We analysed the association between educational level, marital status, having health insurance, having a chronic disease, occupational class, working status and smoking status by using the chi-squared test and logistic regression analysis.

Logistic regression analysis was performed separately in men and women. A large number of women did not work, therefore occupational class was excluded from the logistic regression model for women. Smoking status was the dependent variable, and we included the independent 
variables that were significantly associated with smoking status in the univariate analysis in the logistic regression analysis.

SPSS, version 15.0 was used for data analysis. $P<0.05$ was considered statistically significant.

\section{Ethical considerations}

Dokuz Eylul University Ethical Committee reviewed and approved the study protocol (337/2007). Verbal and written consent was obtained from all the participants.

\section{Results}

Of the total population of people over 30 years of age living in Balcova District of İzmir, 15174 (42\%) participated in the study. Descriptive characteristics of the participants are shown in Table 1. Most of the participants were women [10 $042(66.2 \%)]$ and 8147 (53.7\%) had completed primary school or less. The mean ages of the men and women were 53.1 (SD 13.1) years and 51.3 (SD 13.2) years respectively. The majority of the participants $(80.4 \%)$ were married, $90.5 \%$ had a health insurance and $41.9 \%$ had a chronic disease. As regards smoking, 34.7\% of the participants $(41.7 \%$ of men, $31.2 \%$ of women) were current smokers, $20.2 \%$ (33.1\% of men, $13.5 \%$ of women) were ex-smokers and $45.1 \%$ ( $25.2 \%$ of men, $55.3 \%$ of women) had never smoked. Being a current smoker or an ex-smoker was more common in men than women. Smoking status, age group, educational level, marital status, occupational class, working status and having a chronic disease were significantly different in men and women $(P<0.001)$.

Tables 2 and 3 show the socioeconomic characteristics of the men and women according to smoking status.

\begin{tabular}{|c|c|c|c|c|c|c|c|}
\hline \multirow[t]{2}{*}{ Variable } & \multicolumn{2}{|c|}{$\operatorname{Men}(n=5132)$} & \multicolumn{2}{|c|}{ Women $(n=10042)$} & \multicolumn{2}{|c|}{ Total (15 174) } & \multirow[t]{2}{*}{ P-value $^{\mathrm{a}}$} \\
\hline & No. & $\%$ & No. & $\%$ & No. & $\%$ & \\
\hline Smoking status & & & & & & & $<0.001$ \\
\hline Current smoker & 2139 & 41.7 & 3129 & 31.2 & 5268 & 34.7 & \\
\hline Ex-smoker & 1699 & 33.1 & 1360 & 13.5 & 3059 & 20.2 & \\
\hline Never smoker & 1294 & 25.2 & 5553 & $55 \cdot 3$ & 6847 & 45.1 & \\
\hline Age groups (years) & & & & & & & $<0.001$ \\
\hline $30-44$ & 1500 & 29.2 & 3550 & 35.4 & 5050 & 33.3 & \\
\hline $45-64$ & 2522 & 49.1 & 4711 & 46.9 & 7233 & 47.7 & \\
\hline $65^{+}$ & 1110 & 21.6 & 1781 & 17.7 & 2891 & 19.0 & \\
\hline Educational level & & & & & & & $<0.001$ \\
\hline Primary school or less & 2018 & 39.3 & 6129 & 61.0 & 8147 & 53.7 & \\
\hline Secondary school & 644 & 12.5 & 1022 & 10.2 & 1666 & 11.0 & \\
\hline High school & 1486 & 29.0 & 1935 & 19.3 & 3421 & 22.5 & \\
\hline University or higher & 984 & 19.2 & 956 & 9.5 & 1940 & 12.8 & \\
\hline Marital status & & & & & & & $<0.001$ \\
\hline Other & 507 & 9.9 & 2472 & 24.6 & 2979 & 19.6 & \\
\hline Married & 4625 & 90.1 & 7570 & 75.4 & 12195 & 80.4 & \\
\hline Have health insurance & & & & & & & 0.35 \\
\hline Yes & 4659 & 90.8 & 9069 & 90.3 & 13728 & 90.5 & \\
\hline No & 473 & 9.2 & 973 & 9.7 & 1446 & 9.5 & \\
\hline Have a chronic disease & & & & & & & $<0.001$ \\
\hline Yes & 1902 & 37.1 & 4460 & 44.4 & 6358 & 41.9 & \\
\hline No & 3230 & 62.9 & 5582 & 55.6 & 8816 & 58.1 & \\
\hline Occupational class & & & & & & & $<0.001$ \\
\hline Employer & 326 & 6.4 & 66 & 0.7 & 392 & 2.6 & \\
\hline Self-employed & 584 & 11.4 & 180 & 1.8 & 764 & 5.0 & \\
\hline White collar & 1989 & 38.8 & 1286 & 12.8 & 3275 & 21.6 & \\
\hline Blue collar & 1789 & 34.9 & 758 & 7.5 & 2547 & 16.8 & \\
\hline Unempolyed/no regular income & 444 & 8.7 & 7752 & 77.2 & 8196 & 54.0 & \\
\hline Working status & & & & & & & $<0.001$ \\
\hline Working & 4688 & 91.3 & 2290 & 22.8 & 6978 & 46.0 & \\
\hline Not working & 444 & 8.7 & 7752 & 77.2 & 8196 & 54.0 & \\
\hline
\end{tabular}

${ }^{a}$ Chi-squared test; significant at $P<0.05$. 


\begin{tabular}{|c|c|c|c|c|c|c|c|c|c|}
\hline \multirow[t]{2}{*}{ Variable } & \multicolumn{3}{|c|}{ Current smoker } & \multicolumn{3}{|c|}{ Ex-smoker } & \multicolumn{3}{|c|}{ Never smoker } \\
\hline & No. & $\%$ & $P$-value ${ }^{a}$ & No. & $\%$ & P-value ${ }^{a}$ & No. & $\%$ & P-value a \\
\hline \multicolumn{10}{|l|}{ Educational level } \\
\hline Primary school or less & 862 & 42.7 & $<0.001$ & 692 & 34.3 & $>0.05$ & 464 & 23.0 & $<0.001$ \\
\hline Secondary school & 275 & 42.7 & & 219 & 34.0 & & 150 & 23.3 & \\
\hline High school & 667 & 44.9 & & 461 & 31.0 & & 358 & 24.1 & \\
\hline University or higher & 335 & 34.0 & & 327 & 33.2 & & 322 & 32.7 & \\
\hline \multicolumn{10}{|l|}{ Marital status } \\
\hline Other & 251 & 49.5 & $<0.001$ & 122 & 24.1 & $<0.001$ & 134 & 26.4 & $>0.05$ \\
\hline Married & 1888 & 40.8 & & 1577 & 34.1 & & 1160 & 25.1 & \\
\hline \multicolumn{10}{|l|}{ Occupational class } \\
\hline Employer & 122 & 37.4 & $<0.001$ & 100 & 30.7 & $<0.001$ & 104 & 31.9 & 0.001 \\
\hline Self-employed & 253 & 43.3 & & 180 & 30.8 & & 151 & 25.9 & \\
\hline White collar & 697 & 35.0 & & 761 & 38.3 & & 531 & 26.7 & \\
\hline Blue collar & 812 & 48.1 & & 582 & 34.5 & & 295 & 17.5 & \\
\hline $\begin{array}{l}\text { Unempolyed/no regular } \\
\text { ncome }\end{array}$ & 255 & 57.4 & & 76 & 17.1 & & 113 & 25.5 & \\
\hline \multicolumn{10}{|l|}{ Have health insurance } \\
\hline Yes & 1848 & 39.7 & $<0.001$ & 1626 & 34.9 & $<0.001$ & 1185 & 25.4 & $>0.05$ \\
\hline No & 291 & 61.5 & & 73 & 15.4 & & 109 & 23.0 & \\
\hline \multicolumn{10}{|l|}{ Have a chronic disease } \\
\hline Yes & 546 & 28.7 & $<0.001$ & 872 & 45.9 & $>0.05$ & 482 & 25.4 & $>0.05$ \\
\hline No & 1593 & 49.3 & & 827 & 25.6 & & 812 & 25.1 & \\
\hline
\end{tabular}

${ }^{a}$ Chi-squared test; significant at $P<0.05$.

In both men and women, being a current smoker was significantly more common in people who did not have any health insurance and who did not have a chronic disease $(P<0.001)$.

Table 4 shows the results of the multivariable analysis of the characteristics associated with smoking status in men. Men who had high school education or below, were unemployed or had no regular income, who were blue collar workers, who had no health insurance, and who did not have a chronic disease were significantly more likely to be a current smoker $(P<0.01)$. Men with a university or higher education, who had health insurance and who had a chronic disease had significantly higher odds of being an ex-smoker $(P<0.01)$. In addition, men who worked (employer, self-employed, white collar or blue collar) were more likely to be an ex-smoker than unemployed men ( $P$ $<0.01$ ). Men who had a university or higher education were significantly more likely never to have smoked than men who had a primary school or lower education $(P<$ 0.001)

Table 5 shows the results of the multivariable analysis of the characteristics associated with smoking status in women. Women who had high school education or lower had higher risk of being a current smoker than women who had university or higher education $(P<$ o.oo1). Working women were more likely to be a current smoker than non-working women $(P<0.001)$. Women who had completed a university or higher education had higher odds of being an ex-smoker than women who had completed primary school or lower $(P<0.01)$. Working status and having health insurance were not associated with being an ex-smoker. However, being married and having a chronic disease were $(P=0.02$ and $P=0.001$ respectively). Women who had university or higher education were more likely to have never smoked than those with a high-school education or less. In addition, women who were not working, were more likely never to have smoked than working women $(P=0.001)$.

\section{Discussion}

In this study, while blue-collar workers or unemployed men and men with lower education were more likely to be a current smoker, in women, having a higher education level and working were associated with higher smoking rates.

Several studies have also reported that lower educational level, being a blue-collar worker and having a lower income were associated with increased smoking rates in men (13,20-22). In addition, similar to our findings, other studies have reported that higher educational and social status predisposed to smoking $(13,21,22)$. Most studies report a lower smoking prevalence among women than men (23-25). This may be related to women's attitudes to smoking (26). Smoking prevalence is differentiated by gender. In the beginning of the 2oth century in Western countries, smoking was largely 


\begin{tabular}{|c|c|c|c|c|c|c|c|c|c|}
\hline \multirow[t]{2}{*}{ Variable } & \multicolumn{3}{|c|}{ Current smoker } & \multicolumn{3}{|c|}{ Ex-smoker } & \multicolumn{3}{|c|}{ Never smoker } \\
\hline & No. & $\%$ & $P$-value ${ }^{a}$ & No. & $\%$ & $P$-value ${ }^{a}$ & No. & $\%$ & P-value ${ }^{a}$ \\
\hline \multicolumn{10}{|l|}{ Educational level } \\
\hline Primary school or less & 1516 & 24.7 & $<0.001$ & 773 & 12.6 & $<0.001$ & 3840 & 62.7 & $<0.001$ \\
\hline Secondary school & 430 & 42.1 & & 155 & 15.2 & & 437 & 42.8 & \\
\hline High school & 847 & 43.8 & & 275 & 14.2 & & 813 & 42.0 & \\
\hline University or higher & 336 & 35.1 & & 157 & 16.4 & & 463 & 48.4 & \\
\hline \multicolumn{10}{|l|}{ Marital status } \\
\hline Other & 702 & 28.4 & $<0.001$ & 367 & 14.8 & $<0.001$ & 1403 & 56.8 & $>0.05$ \\
\hline Married & 2427 & 32.1 & & 993 & 13.1 & & 4150 & 54.8 & \\
\hline \multicolumn{10}{|l|}{ Working status } \\
\hline Worker $^{b}$ & 828 & 36.2 & $<0.001$ & 380 & 16.6 & $>0.05$ & 1082 & 47.2 & $<0.001$ \\
\hline Not a worker & 2301 & 29.7 & & 980 & 12.6 & & 4471 & 57.7 & \\
\hline \multicolumn{10}{|l|}{ Have health insurance } \\
\hline Yes & 2741 & 30.2 & $<0.001$ & 1249 & 13.8 & $<0.001$ & 5079 & 56.0 & $<0.001$ \\
\hline No & 388 & 39.9 & & 111 & 11.4 & & 474 & 48.7 & \\
\hline \multicolumn{10}{|l|}{ Have a chronic disease } \\
\hline Yes & 1036 & 23.2 & $<0.001$ & 690 & 15.5 & $<0.001$ & 2732 & 61.3 & $<0.001$ \\
\hline No & 2093 & 37.5 & & 670 & 12.0 & & 2821 & 50.5 & \\
\hline
\end{tabular}

${ }^{a}$ Chi-squared test; significant at $P<0.05$.

${ }^{b}$ Having income-generating work.

\begin{tabular}{|c|c|c|c|c|c|c|}
\hline \multirow[t]{2}{*}{ Characteristic } & \multicolumn{2}{|c|}{ Current smoker } & \multicolumn{2}{|c|}{ Ex-smoker } & \multicolumn{2}{|c|}{ Never smoker } \\
\hline & $P$-value & OR $(95 \% \mathrm{CI})$ & $P$-value & OR $(95 \% \mathrm{CI})$ & $P$-value & OR $(95 \% \mathrm{CI})$ \\
\hline \multicolumn{7}{|l|}{ Educational level } \\
\hline Primary school or less & 0.001 & $1.84(1.51-2.26)$ & - & 1.00 & - & 1.00 \\
\hline Secondary school & 0.001 & $1.62(1.29-2.03)$ & 0.38 & $1.11(0.88-1.39)$ & 0.77 & $1.03(0.83-1.28)$ \\
\hline High school & 0.001 & $1.71(1.43-2.04)$ & 0.97 & $0.99(0.82-1.21)$ & 0.20 & $1.12(0.94-1.34)$ \\
\hline University or higher a & - & 1.00 & 0.001 & $1.49(1.17-1.89)$ & $<0.001$ & $1.75(1.41-2.15)$ \\
\hline \multicolumn{7}{|l|}{ Marital status } \\
\hline Other & 0.97 & $0.99(0.81-1.22)$ & - & 1.00 & - & 1.00 \\
\hline Married $^{\mathrm{a}}$ & - & 1.00 & 0.07 & $1.28(0.98-1.67)$ & 0.45 & $0.92(0.74-1.14)$ \\
\hline \multicolumn{7}{|l|}{ Occupational class } \\
\hline Employer $^{\mathrm{a}}$ & - & 1.00 & 0.01 & $1.76(1.16-2.67)$ & 0.18 & $1.26(0.90-1.77)$ \\
\hline Self-employed & 0.25 & $1.19(0.89-1.59)$ & 0.01 & $1.66(1.16-2.38)$ & 0.95 & $0.99(0.73-1.34)$ \\
\hline White collar & 0.18 & $1.20(0.92-1.56)$ & 0.001 & $1.82(1.30-2.56)$ & 0.17 & $0.82(0.62-1.09)$ \\
\hline Blue collar & 0.03 & $1.33(1.03-1.71)$ & 0.01 & $1.55(1.12-2.14)$ & 0.12 & $0.81(0.62-1.05)$ \\
\hline $\begin{array}{l}\text { Unempolyed/no regular } \\
\text { income }\end{array}$ & 0.01 & $1.60(1.15-2.21)$ & - & 1.00 & - & 1.00 \\
\hline \multicolumn{7}{|l|}{ Have health insurance } \\
\hline Yes $^{\text {a }}$ & - & 1.00 & 0.01 & $1.54(1.13-2.10)$ & 0.28 & $1.15(0.89-1.49)$ \\
\hline No & 0.01 & $1.40(1.11-1.76)$ & - & 1.00 & - & 1.00 \\
\hline \multicolumn{7}{|l|}{ Have a chronic disease } \\
\hline Yes $^{\text {a }}$ & - & 1.00 & 0.001 & $1.91(1.64-2.22)$ & - & 1.00 \\
\hline No & 0.001 & $1.67(1.47-1.91)$ & - & 1.00 & 0.85 & $1.01(0.88-1.17)$ \\
\hline
\end{tabular}

${ }^{a}$ Reference category.

Variables were adjusted for all other variables and age.

$\mathrm{OR}=$ odds ratio, $\mathrm{CI}=$ confidence interval. 


\begin{tabular}{|c|c|c|c|c|c|c|}
\hline \multirow[t]{2}{*}{ Characteristic } & \multicolumn{2}{|c|}{ Current smoker } & \multicolumn{2}{|c|}{ Ex-smoker } & \multicolumn{2}{|c|}{ Never smoker } \\
\hline & P-value & OR $(95 \% \mathrm{CI})$ & P-value & OR $(95 \% \mathrm{CI})$ & $P$-value & OR $(95 \% \mathrm{CI})$ \\
\hline \multicolumn{7}{|l|}{ Educational level } \\
\hline Primary school or less & 0.04 & $1.19(1.01-1.42)$ & - & 1.00 & 0.98 & $0.99(0.85-1.17)$ \\
\hline Secondary school & 0.001 & $1.99(1.63-2.43)$ & 0.51 & $0.93\left(0.75^{-1.15}\right)$ & 0.001 & $0.55(0.46-0.67)$ \\
\hline High school & 0.001 & $1.66(1.39-1.97)$ & 0.82 & $0.98(0.82-1.17)$ & 0.001 & $0.65(0.55-0.77)$ \\
\hline University or higher a & - & 1.00 & 0.01 & $1.43(1.11-1.84)$ & - & 1.00 \\
\hline \multicolumn{7}{|l|}{ Marital status } \\
\hline Other & 0.001 & $1.35(1.21-1.51)$ & - & 1.00 & - & 1.00 \\
\hline Married a & - & 1.00 & 0.02 & $1.22(1.03-1.43)$ & 0.001 & $1.34(1.21-1.48)$ \\
\hline \multicolumn{7}{|l|}{ Working status } \\
\hline Worker ${ }^{b}$ & 0.001 & $1.30\left(1.15^{-1.46)}\right.$ & 0.91 & $0.99(0.84-1.17)$ & - & 1.00 \\
\hline Not a worker & - & 1.00 & - & 1.00 & 0.001 & $1.40(1.25-1.56)$ \\
\hline \multicolumn{7}{|l|}{ Have health insurance } \\
\hline Yes $^{a}$ & - & 1.00 & 0.39 & $1.11(0.88-1.40)$ & 0.05 & $1.15(0.99-1.32)$ \\
\hline No & 0.04 & $1.16(1.01-1.35)$ & - & 1.00 & - & 1.00 \\
\hline \multicolumn{7}{|l|}{ Have a chronic disease } \\
\hline Yes $^{\text {a }}$ & - & 1.00 & 0.001 & $1.30(1.12-1.50)$ & - & 1.00 \\
\hline No & 0.03 & $1.12(1.01-1.23)$ & - & 1.00 & 0.83 & $1.01(0.92-1.11)$ \\
\hline
\end{tabular}

aReference category.

${ }^{b}$ Having income-generating work.

Variables were adjusted for all other variables and age.

$\mathrm{OR}=$ odds ratio, $\mathrm{CI}=$ confidence interval .

restricted to males and it was an inappropriate and shameful behaviour in women $(26,27)$. This lower rate of smoking among women continued until smoking in women became more accepted by society. Indeed, the gender gap in cigarette consumption has narrowed because smoking among women has been spreading rapidly since the 1920s, especially in working women (27): employed women have had more access to money with which to buy cigarettes. Moreover, smoking was seen as a symbol of gender equality, independence and modernity (26). Recently, because of low rates of smoking among women, the tobacco industry has targeted women, especially in developing countries (28). Some tobacco companies target women through commercials with messages that smoking signifies freedom, independence and power (29). This concurs with our finding that single women had a higher risk of being a current smoker. However, a study in Serbia found that living alone or being divorced significantly increased the prevalence of smoking in both sexes (21). According to a Korean study, the age-adjusted smoking rate for the unmarried was higher than for the married in both sexes (30). However, in our study, there was no relationship between men's smoking habits and their marital status.

As reported in other studies (31-33), our study shows that unemployment was associated with a higher smoking prevalence in men. However, no association was seen between unemployment and being a current smoker in women in our study. Although, Balcova is one of the most developed districts of Izmir, participation of women in the workforce is lower than men (18). Therefore, unemployment may not be an indicator of social status among women.

In our study, ex-smokers were defined as people who reported cigarette smoking during their lifetime but had not smoked for at least 1 month before being interviewed. Thus, we evaluated smoking cessation as being an exsmoker. Our study did not show an association between being an ex-smoker and educational level for either gender. A study conducted in Vietnam indicated that higher educational level increased the likelihood of the decision to stop smoking (34). Studies have found that more highly educated people are more successful in smoking cessation $(21,34,35)$.

It has been reported that more employed men quit smoking than unemployed men (36-38), which is what we found in our study. However, there was no relationship between working status and being an ex-smoker among women in our study.

People who did not have a chronic disease were more likely to be current smokers, in both men and women in our study. Furthermore, having a chronic disease was significantly associated with being an ex-smoker in both sexes. A study in Turkey in 2009-2011 showed higher smoking cessation success among those with a chronic disease, especially among elderly people who had at least 1 chronic disease (14). Another study demonstrated that one of the most common reasons for smoking cessation was doctors' advice after the diagnosis of a chronic disease (39). 
Our population-based study included a very large group from an urban district. This large number provided an opportunity to show the association between social characteristics and smoking habits in the community. However, our study has some limitations. The data on smoking habits were self-reported, and were recorded in face-to-face interviews with the participants. The low participation rate of men and employed women was the main limitation. Because of this, women's smoking habits could not be evaluated according to occupational class. We did not evaluate the differences of social status between the participants and other people who live in Balcova who did not agree to participate to the study because data were not recorded on the non-participants. Although financial circumstances may indicate social status, we had no data on their economic status or income. Our study included people over the age of 30 years, so the social factors related to smoking in those under 30 years of age were not evaluated.

This study highlights that the socioeconomic circumstances of the population play an important role in determining their smoking habits. Tobacco control strategies should be devised with the characteristics of the target population in mind. Some strategies are more effective in preventing smoking among populations of low socioeconomic status, such as prohibiting smoking in all indoor spaces with comprehensive smoke-free air laws, increasing tobacco prices, and providing accessible, affordable and evidence-based smoking cessation services. Hard-hitting mass media campaigns targeting less advantaged populations can help improve awareness among this sector of society about the hazards of tobacco smoking (9).

\section{Conclusions}

Socially disadvantaged groups of men, especially those who had a low level of education or were unemployed, were more likely to be current smokers, and smoking cessation was lower in these groups. The relationship between socioeconomic factors and smoking habits showed differences between men and women. More population-based countrywide studies should be done to understand the trends in smoking as they relate to socioeconomic factors. Socioeconomic factors should always be taken into consideration when planning and implementing smoking cessation policies.

Funding: The project was jointly funded by the Balcova Municipality and the DEU Research Fund (grant number: 2007161).

Competing interests: None declared.

\section{Facteurs socio-économiques associés au tabagisme en Turquie : étude populationnelle transversale \\ Résumé}

Contexte : Le genre et un faible niveau socio-économique sont associés au tabagisme.

Objectifs : La présente étude avait pour objectif de déterminer l'association entre les facteurs socio-économiques et la consommation de cigarette à Balçova, dans le district d'Izmir en Turquie, en se concentrant sur les différences entre les sexes.

Méthodes : La population de l'étude était constituée de l'ensemble des hommes et des femmes (36 187) âgés de plus de 30 ans et vivant à Balçova d'octobre 2007 à mai 2009. Les données ont été recueillies au cours d'entretiens et incluaient le statut tabagique (au moment de l'étude, antérieur, jamais), l'âge, le sexe, la situation matrimoniale, le niveau d'éducation, la classe professionnelle/le statut professionnel, le fait de posséder une assurance maladie et d'être atteint d'une maladie chronique. Une analyse de régression logistique a été utilisée pour évaluer l'association entre les caractéristiques socioéconomiques et le statut tabagique.

Résultats : Sur les 36187 sujets de l'étude, 16080 (44\%) ont accepté de participer et $15174(42 \%)$, pour lesquels des données complètes avaient été fournies, ont fait l'objet d'une évaluation. Il s'agissait en majorité de femmes $(66,2 \%) ; l$ lâge moyen des hommes et des femmes étaient 53,1 (ET 13,1) et 51,3 (ET 13,2) respectivement. Les fumeurs au moment de l'étude étaient plus nombreux parmi les hommes ( $41,7 \%$ contre $31,2 \%$ de femmes) et davantage d'hommes étaient des anciens fumeurs ( $33,1 \%$ contre $13,5 \%$ de femmes), tandis que davantage de femmes n'avaient jamais fumé $(55,3 \%$ contre $25,2 \%$ d'hommes). Pour les femmes, être mariées et avoir un faible niveau d'éducation étaient associés au fait de fumer et d'avoir fumé $(p<0,05)$. Le tabagisme était aussi plus fréquent chez les femmes actives $(p<0,05)$. Pour les hommes, un faible niveau d'éducation et la classe professionnelle étaient associés au fait de fumer ou d'être un ancien fumeur $(p<0,05)$.

Conclusions : Les groupes socialement défavorisés, particulièrement ceux ayant un faible niveau d'éducation ou les hommes sans emploi, étaient plus susceptibles d'être fumeurs et le sevrage tabagique était moins fréquent dans ces groupes. Les habitudes liées au tabagisme variaient entre les hommes et les femmes. Les facteurs socio-économiques devraient toujours être pris en compte dans l'élaboration de politiques concernant le sevrage tabagique. 


\section{العو امل الاجتهاعية والاقتصادية المرتبطة بتدخين التبخ في تركيا: دراسة مقطعية سكانية

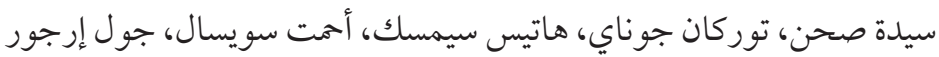 الخلاصة}

الخلفية: يرتبط النوع وانخفاض الوضع الاجتماعي والاقتصادي بالتدخين. الأهداف: هدفت هذه الدراسة إلى تحديد العلاقة بين العوامل الاجتماعية والاقتصادية وبين تدخين السجائر التئر في بالكوفا، أزمير، تركيا، مع التركيز على الفروق بين الجنسين.

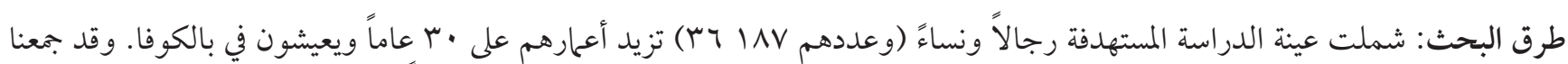

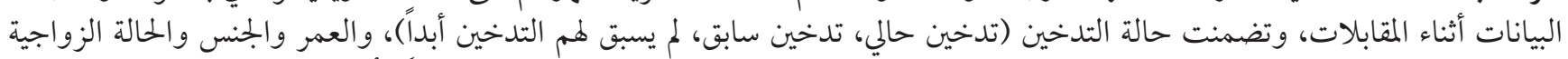

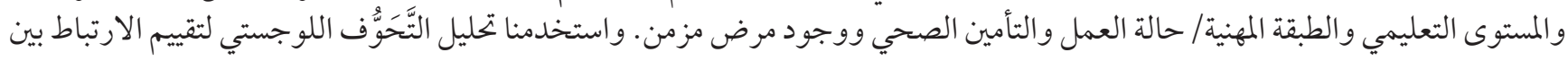
الخصائص الاجتماعية والاقتصادية وبين حالة التدخين.

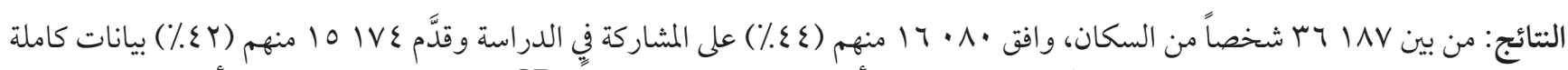

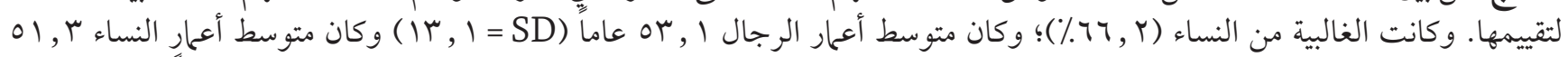

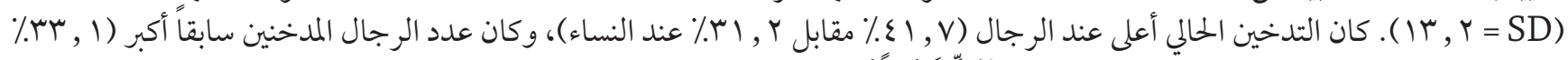

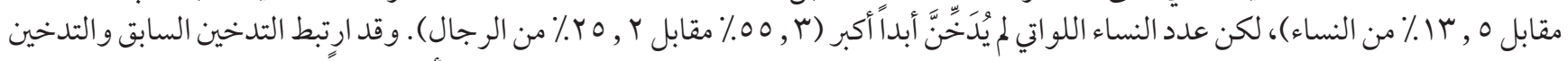

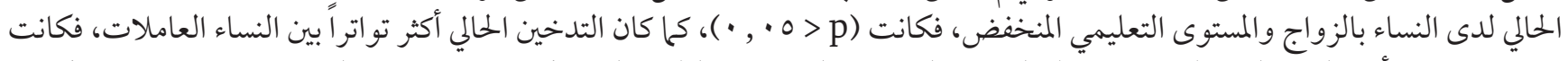

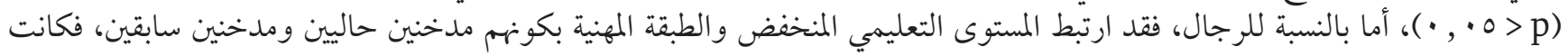
$(\cdot, \cdot \circ>\mathrm{p})$

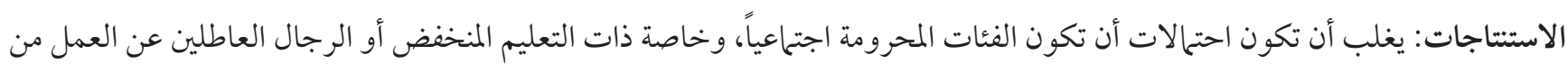

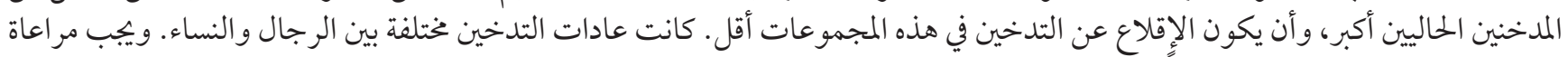

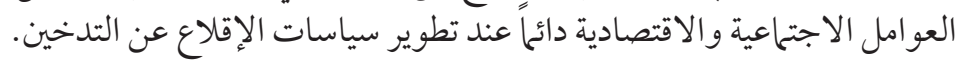

\section{References}

1. Closing the gap in a generation: health equity through action on the social determinants of health. Final Report of the Commission on Social Determinants of Health. Geneva: World Health Organization; 2008.

2. Best practices for comprehensive tobacco control programs. Atlanta: US Department of Health and Human Services, Centers for Disease Control and Prevention; 2014.

3. World health statistics. Geneva: World Health Organization; 2012.

4. Doganay SSK, Kalaca S, Unal B. How has the prevalence of smoking changed in Turkey? Turk J Public Health. 2012;10(2):93-115.

5. Sozmen K, Unal B, Saidi O, Romdhane HB, Abu-Rmeileh NM, Husseini A, et al. Cardiovascular risk factor trends in the Eastern Mediterranean region: evidence from four countries is alarming. Int J Public Health. 2015 Jan;60 Suppl 1:S3-11 https://doi. org/10.1007/s00038-014-0610-6 PMID:25280526

6. Global Adult Tobacco Survey Turkey 2012. Ankara: Public Health Institution of Turkey; 2014.

7. World Health Organization. Social determinants of health [webpage] (http://www.who.int/social_determinants/sdh_definition/ en/, accessed 28 February 2018).

8. Oakes JM, Rossi PH. The measurement of SES in health research: current practice and steps toward a new approach. Soc Sci Med. 2003 Feb;56(4):769-84. https://doi.org/10.1016/S0277-9536(02)00073-4 PMID:12560010

9. Garrett BE, Dube SR, Babb S, McAfee T. Addressing the social determinants of health to reduce tobacco-related disparities. Nicotine Tob Res. 2015 Aug;17(8):892-7. https://doi.org/10.1093/ntr/ntu266 PMID:25516538

10. Watson JM, Scarinci IC, Klesges RC, Murray DM, Vander Weg M, DeBon M, et al. Relationships among smoking status, ethnicity, socioeconomic indicators, and lifestyle variables in a biracial sample of women. Prev Med. 2003 Aug;37(2):138-47. https://doi. org/10.1016/Soog1-7435(03)00096-3 PMID:12855213

11. Laaksonen M, Prättälä R, Helasoja V, Uutela A, Lahelma E. Income and health behaviours. Evidence from monitoring surveys among Finnish adults. J Epidemiol Community Health. 2003 Sep;57(9):711-7. https://doi.org/10.1136/jech.57.9.711 PMID:12933778

12. Lopez AD, Collinshaw NE, Tipa P. A descriptive model of the cigarette epidemic in developed countries. Tob Control. 1994;3(3):242-7. https://doi.org/10.1136/tc.3.3.242

13. Cavelaars AE, Kunst AE, Geurts JJ, Crialesi R, Grötvedt L, Helmert U, et al. Educational differences in smoking: international comparison. BMJ. 2000 Apr 22;320(7242):1102-7. https://doi.org/10.1136/bmj.320.7242.1102 PMID:10775217

14. Gunay T, Pekel O, Simsek H, Sahan C, Soysal A, Kilinc O, et al. Smoking habits and cessation success. What differs among adults and elderly? Saudi Med J. 2014 Jun;35(6):585-91. PMID:24888658 
15. Pekel Ö, Ergör G, Günay T, Baydur H, Choussein B, Budak R, et al. Smoking cessation and the effect of nicotine dependence on relapse rate in Izmir, Turkey. Turk J Med Sci. 2015;45(4):895-901. https://doi.org/10.3906/sag-1408-55 PMID:26422864

16. Ergör G, Soysal A, Sözmen K, Ünal B, Uçku R, Kılıç B, et al. Balcova heart study: rationale and methodology of the Turkish cohort. Int J Public Health. 2012 Jun;57(3):535-42. https://doi.org/10.1007/s00038-011-0309-x PMID:21987028

17. Unal B, Sozmen K, Ucku R, Ergor G, Soysal A, Baydur H, et al. High prevalence of cardiovascular risk factors in a Western urban Turkish population: a community-based study. Anadolu Kardiyol Derg. 2013 Feb;13(1):9-17. https://doi.org/10.5152/akd.2013.002 PMID:23070631.

18. Bugra A, Yakut-Cakar B. Structural change, the social policy environment and female employment in Turkey. Dev Change. 2010;41(3):517-38. https://doi.org/10.1111/j.1467-7660.2010.01643.X

19. Giray Simsek H, Gunay T, Ucku R. [Effects of social inequalities on coronary heart disease risk factors: a population-based, cross-sectional study in Izmir]. Anadolu Kardiyol Derg. 2010 Jun;10(3):193-201. https://doi.org/10.5152/akd.2010.057 PMID:20538552 [In Turkish]

20. Barbeau EM, Krieger N, Soobader MJ. Working class matters: socioeconomic disadvantage, race/ethnicity, gender, and smoking in NHIS 2000. Am J Public Health. 2004 Feb;94(2):269-78. https://doi.org/10.2105/AJPH.94.2.269 PMID:14759942

21. Djikanovic B, Marinkovic J, Jankovic J, Vujanac V, Simic S. Gender differences in smoking experience and cessation: do wealth and education matter equally for women and men in Serbia? J Public Health (Oxf). 2011 Mar;33(1):31-8. https://doi.org/10.1093/ pubmed/fdq080 PMID:20952438

22. El Rhazi K, Nejjari C, Berraho M, Serhier Z, Tachfouti N, El Fakir S, et al. Inequalities in smoking profiles in Morocco: the role of educational level. Int J Tuberc Lung Dis. 2008 Nov;12(11):1327-32. PMID:18926045.

23. Syamlal G, Mazurek JM, Dube SR. Gender differences in smoking among U.S. working adults. Am J Prev Med. 2014 Oct;47(4):467-75. https://doi.org/10.1016/j.amepre.2014.06.013 PMID:25049215

24. Coste J, Quinquis L, D'Almeida S, Audureau E. Smoking and health-related quality of life in the general population. Independent relationships and large differences according to patterns and quantity of smoking and to gender. PLoS One. 201403 17;9(3):e91562. https://doi.org/10.1371/journal.pone.0091562 PMID:24637739

25. Hitchman SC, Fong GT. Gender empowerment and female-to-male smoking prevalence ratios. Bull World Health Organ. 2011 Mar 1;89(3):195-202. https://doi.org/10.2471/BLT.10.079905 PMID:21379415

26. Flandorfer P, Wegner C, Buber I. Gender Roles and Smoking Behaviour. Vienna: Vienna Institute of Demography, Austrian Academy of Sciences; 2010:7.

27. Lopez AD, Mathers CD, Ezzati M, Jamison DT, Murray CJ. Global and regional burden of disease and risk factors, 2001: systematic analysis of population health data. Lancet. 2006 May 27;367(9524):1747-57. https://doi.org/10.1016/So140-6736(06)68770-9 PMID:16731270

28. Oztoprak SD, GT. [Gender and tobacco control for health.] Turk J Public Health. 2013;11(3):197-206. [In Turkish]

29. Influencing tobacco use among women in Surgeon General's Report: woman and smoking. Atlanta: Department of Health and Human Services, Centers for Disease Control and Prevention; 2001.

30. Cho HJ, Khang YH, Jun HJ, Kawachi I. Marital status and smoking in Korea: the influence of gender and age. Soc Sci Med. 2008 Feb;66(3):609-19. https://doi.org/10.1016/j.socscimed.2007.10.005 PMID:17996346

31. Khlat M, Sermet C, Le Pape A. Increased prevalence of depression, smoking, heavy drinking and use of psycho-active drugs among unemployed men in France. Eur J Epidemiol. 2004;19(5):445-51. https://doi.org/10.1023/B:EJEP.0000027356.71414.bd PMID:15233317

32. Fagan P, Shavers V, Lawrence D, Gibson JT, Ponder P. Cigarette smoking and quitting behaviors among unemployed adults in the United States. Nicotine Tob Res. 2007 Feb;9(2):241-8. PMID:17365755

33. Arcaya M, Glymour MM, Christakis NA, Kawachi I, Subramanian SV. Individual and spousal unemployment as predictors of smoking and drinking behavior. Soc Sci Med. 2014 Jun;110:89-95. https://doi.org/10.1016/j.socscimed.2014.03.034 PMID:24727666

34. de Walque D. Does education affect smoking behaviors? Evidence using the Vietnam draft as an instrument for college education. J Health Econ. 2007 Sep 1;26(5):877-95. https://doi.org/10.1016/j.jhealeco.2006.12.005 PMID:17275938

35. Nagelhout GE, Crone MR, van den Putte B, Willemsen MC, Fong GT, de Vries H. Age and educational inequalities in smoking cessation due to three population-level tobacco control interventions: findings from the International Tobacco Control (ITC) Netherlands Survey. Health Educ Res. 2013 Feb;28(1):83-91. https://doi.org/10.1093/her/cys101 PMID:23087009

36. Paavola M, Vartiainen E, Puska P. Smoking cessation between teenage years and adulthood. Health Educ Res. 2001 Feb;16(1):4957. https://doi.org/10.1093/her/16.1.49 PMID:11252283

37. Businelle MS, Kendzor DE, Reitzel LR, Costello TJ, Cofta-Woerpel L, Li Y, et al. Mechanisms linking socioeconomic status to smoking cessation: a structural equation modeling approach. Health Psychol. 2010 May;29(3):262-73. https://doi.org/10.1037/ ao019285 PMID:20496980.

38. Foulds J, Gandhi KK, Steinberg MB, Richardson DL, Williams JM, Burke MV, et al. Factors associated with quitting smoking at a tobacco dependence treatment clinic. Am J Health Behav. 2006 Jul-Aug;30(4):400-12. https://doi.org/10.5993/AJHB.30.4.6 PMID:16787130

39. Ben-Noun L, Biderman A, Shvartzman P. Patients' smoking status: the family practice physician's view. Isr Med Assoc J. 2000 May;2(5):351-5. PMID:10892388 